\title{
PENGARUH KOMPETENSI GURU TERHADAP HASIL BELAJAR MATA PELAJARAN EKONOMI SISWA KELAS XI SMA PGRI 109 KOTA TANGERANG
}

\author{
SOFFI SOFFIATUN ${ }^{1)}$, BADRIANAH ${ }^{2)}$ \\ ${ }^{1,}$ Dosen Program Studi Pendidikan Ekonomi Universitas Pamulang \\ ${ }^{2}$ Mahasiswa Program Studi Pendidikan Ekonomi Universitas Pamulang \\ ${ }^{*}$ email: ${ }^{1)}$ dpriza@gmail.com
}

\begin{abstract}
ABSTRAK
Kompetensi guru merupakan suatu keterampilan yang wajib dimiliki oleh setiap guru untuk menunjang pelaksanaan kegiatan profesinya sebagai tenaga pendidik. Kompetensi tersebut mencakup kompetensi pedagogis, sosial, kepribadian dan profesional sebagai suatu kesatuan. Dengan adanya kompetensi tersebut diharapkan guru dapat memotivasi siswa untuk belajar lebih baik, sehingga hasil belajar yang diharapkan berupa pencapaian yang memuaskan. Penelitian ini mengkaji mengenai pengaruh kompetensi guru terhadap hasil belajar mata pelajaran ekonomi siswa kelas XI.Yang menjadi subjek dalam penelitian ini adalah siswa kelas XI SMA PGRI 109 Kota Tangerang.

Tujuan dari penelitian ini adalah untuk mengetahui pengaruh yang dihasilkan oleh kompetensi guru terhadap hasil belajar siswa pada mata pelajaran Ekonomi di kelas XI. Pendekatan yang digunakan dalam penelitian ini adalah pendekatan kuantitatif dengan metode deskriptif, yaitu pencatatan dan penganalisaan data melalui perhitungan statistik terhadap masalah yang sedang terjadi sekarang ini. Adapun pengumpulan data dilakukan melalui penyebaran angket, wawancara, dokumentasi dan observasi lapangan.

Hasil penelitian yang diperoleh menunjukan bahwa: 1) Tingkat kompetensi guru di SMA PGRI 109 Kota Tangerang sesuai distribusi data yang diperoleh berada ditingkat yang baik. 2) Hasil belajar mata pelajaran Ekonomi siswa kelas XI SMA PGRI 109 Kota Tangerang berdasarkan hasil angket dan data nilai siswa menunjukan hasil yang baik. 3) Terdapat pengaruh kompetensi guru terhadap hasil belajar mata pelajaran Ekonomi siswa kelas XI SMA PGRI 109 Kota Tangerang dengan angka koefisien regresi sebesar 0,186 dan thitung 5,109 > ttabel 1,664. Pengaruh yang dihasilkan oleh kompetensi guru terhadap hasil belajar adalah sebesar 18,1\% dengan R Square 0,181.Dengan demikian dapat disimpulkan bahwa pengaruh kompetensi guru terhadap hasil belajar siswa sebesar $18,1 \%$ sedang sisanya $81,9 \%$ dipengaruhi oleh faktor-faktor lain di luar penelitian ini.
\end{abstract}

\section{Kata Kunci: Kompetensi Guru, Hasil Belajar}




\section{PENDAHULUAN}

\section{A. Latar Belakang Masalah}

Globalisasi ekonomi yang terjadi sekarang ini, diiringi pesatnya perkembangan ilmu pengetahuan dan teknologi telah merubah dunia menjadi satu kota besar yang penuh persaingan. Sumber daya manusia yang berkualitas dan memiliki keterampilan serta daya saing tinggi menjadi salah satu faktor kunci dalam persaingan global. Menghadapi tantangan demikian, dibutuhkan peran aktif dunia pendidikan dalam menciptakan sumber daya manusia Indonesia yang siap dan mampu bersaing di era globalisasi.

Pendidikan memegang peranan penting dalam kemajuan suatu bangsa, karena akan mempengaruhi produktifitas dan kualitas sumber daya manusianya. Undang-Undang dasar Republik Indonesia No. 20 tahun 2003 menjelaskan arti dan tujuan pendidikan nasional, yaitu: Pendidikan Nasional merupakan suatu usaha sadar dan terencana dalam rangka mewujudkan suasana belajar dan proses pembelajaran agar peserta didik dapat secara aktif mengembangkan potensi dirinya untuk memiliki kekuatan spiritual, keagamaan, pengendalian diri, kebiasaan, kecerdasan dan keterampilan yang diperlukan bagi dirinya, masyarakat, bangsa dan Negara.

Salah satu tolak ukur keberhasilan kegiatan pendidikan di sekolah dapat tercermin melalui hasil belajar yang dicapai oleh peserta didik. K.H. R. Fananie (2010: xxxiii) menyatakan bahwa keberhasilan pendidikan ditentukan dari kemampuan anak didik menerapkan ilmu yang diperolehnya kedalam kehidupan nyata dan pergaulan sosial.

Sekolahan itu merupakan anak tangga atau titik pendakian menuju "gunung pergaulan hidup" yang akan mengandung beberapa macam cobaan dan kesukaran. Sekolahan merupakan dunia pergaulan kecil atau "miniatur kehidupan" yang sebenarnya, yang sesuai dengan tingkat penerimaan akal peserta didik. Sekolahan harus bisa memberikan gambaran dari kekhasan dunia kehidupan yang sebenarnya (yaitu masyarakat).

Hasil belajar yang baik akan tercermin melalui perubahan perilaku yang disebabkan oleh adanya proses belajar. Untuk mempermudah dalam 
memahami dan mengukur perubahan perilaku sebagai hasil belajar, Benjamin S. Bloom menggolongkan tujuan belajar ke dalam tida domain, yaitu: kognitif, afektif dan psikomotorik (Purwanto, 2014: 50). Teori ini dikenal dengan istilah "Taksonomi Bloom". Dengan demikian hasil belajar tidak selalu dapat diukur secara kuantitatif melalui nilai atau angka, melainkan juga secara kualitatif terkait perubahan peserta didik baik secara kogntif, afektif maupun psikomotorik.

Guru sebagai salah satu komponen dan pelaksana program pendidikan di sekolah memegang peranan penting serta tanggungjawab yang besar, baik secara moral maupun profesional dalam keberhasilan kegiatan pembelajaran dan pencapaian tujuan pendidikan nasional. Berdasarkan pertimbangan tersebut, pemerintah mengeluarkan UndangUndang No. 14 tahun 2005 tentang Guru dan Dosen. Dalam pasal 1 ayat 1, ditegaskan bahwa tugas utama guru adalah mendidik, mengajar, membimbing, mengarahkan, melatih, menilai dan mengevaluasi peserta didik pada pendidikan anak usia dini jalur pendidikan formal, pendidikan dasar, dan pendidikan menengah. Disamping tugas utama tersebut, pada pasal 4 juga dicantumkan peran guru sebagai agen pembelajaran yang berfungsi untuk meningkatkan mutu pendidikan nasional. Yang dimaksud sebagai agen pembelajaran adalah peran guru yang lebih luas, antara lain sebagai motivator, inspirator, fasilitator, dan perekayasa pembelajaran agar menyenangkan sehingga dapat meningkatkan hasil belajar siswa. Jadi tugas guru bukan hanya terfokus pada transfer ilmu saja melainkan mampu mengubah pola fikir, sikap dan tingkah laku.

Untuk dapat memenuhi tugas dan tanggungjawab besar tersebut, dibutuhkan keahlian dan kompetensi tertentu yang harus dimiliki oleh seorang guru. Menurut Peraturan Pemerintah No. 19 tahun 2005 tentang Standar Pendidikan Nasional, kompetensi yang harus dipenuhi oleh seorang guru meliputi "kompetensi pedagogis, kompetensi kepribadian, kompetensi profesional, dan kompetensi sosial". Kompetensi pedagogis merupakan kemampuan yang berkaitan dengan perancangan dan pelaksanaan pembelajaran, evaluasi hasil belajar dan pemahaman serta pengembangan potensi perserta didik. Kompetensi 
kepribadian adalah kemampuan personal yang mencerminkan kepribadian dan akhlak yang baik dari seorang guru agar dapat menjadi teladan bagi peserta didik. Kompetensi profesional merupakan kemampuan dalam memahami isi materi kurikulum dan penguasaan bahan ajar secara luas dan mendalam. Adapun kompetensi sosial adalah kemampuan personal seorang guru dalam berkomunikasi dan berinteraksi secara baik dengan masyarakat dan lingkungannya. Keempat kompetensi di atas merupakan satu kesatuan yang tidak dapat dipisahkan untuk mendukung keberhasilan kegiatan pendidikan.

SMA PGRI 109 yang berlokasi di Jl. Untung Suropati No. 2, Cimone Jaya, Karawaci, Kota Tangerang merupakan salah satu sekolah menengah tingkat atas yang cukup dikenal oleh masyarakat sekitar Kota Tangerang. SMA PGRI 109 Kota Tangerang telah berdiri selama 28 tahun dan memiliki akreditasi A, namun hingga saat ini belum ada prestasi yang menonjol dari siswanya terkait mata pelajaran Ekonomi. Hal tersebut menarik minat penulis untuk melakukan penelitian terkait kompetensi guru dan pengaruhnya terhadap hasil belajar mata pelajaran Ekonomi di SMA PGRI 109 Kota Tangerang.

Dalam rangka untuk mengetahui sejauh mana pengaruh kompetensi guru terhadap keberhasilan hasil belajar siswa, khususnya dalam mata pelajaran Ekonomi, penulis memilih penelitian dengan judul "Pengaruh Kompetensi Guru Terhadap Hasil Belajar Mata Pelajaran Ekonomi Siswa Kelas XI SMA PGRI 109 Kota Tangerang”.

\section{B. Identifikasi Masalah}

Berdasarkan judul di atas serta agar penelitian dapat lebih terarah dan jelas, penulis melakukan identifikasi masalah sebagai berikut:

1. Kurangnya kompetensi guru mata pelajaran Ekonomi untuk dapat meningkatkan hasil belajar siswa.

2. Lemahnya pengawasan terhadap standar kompetensi guru mata pelajaran Ekonomi dalam meningkatkan hasil belajar siswa.

3. Kurangnya minat dan motivasi siswa terhadap mata pelajaran Ekonomi sehingga pencapaian hasil belajar kurang maksimal. 


\section{Tujuan Penelitian}

Adapun tujuan dari penelitian ini adalah untuk:

1. Mengetahui kompetensi guru mata pelajaran Ekonomi siswa kelas XI di SMA PGRI 109 Kota Tangerang.

2. Mengetahui hasil belajar mata pelajaran Ekonomi siswa kelas XI di SMA PGRI 109 Kota Tangerang.

3. Mengetahui pengaruh yang dihasilkan oleh kompetensi guru terhadap hasil belajar mata pelajaran Ekonomi siswa kelas XI di SMA PGRI 109 Kota Tangerang.

\section{Hipotesis Penelitian}

Menurut Sugiyono (2009: 96), hipotesis merupakan jawaban sementara terhadap rumusan masalah dalam suatu penelitian, di mana rumusan masalah penelitian telah dinyatakan dalam bentuk pertanyaan. Berdasarkan definisi tersebut, penulis merumuskan hipotesis atas rumusan masalah dalam penelitian ini sebagai berikut:

Hipotesis alternatif $\left(\mathrm{H}_{\mathrm{a}}\right)$ : Diduga terdapat pengaruh kompetensi guru terhadap hasil belajar mata pelajaran Ekonomi siswa kelas XI SMA PGRI 109 Kota Tangerang.

\section{METODE PENELITIAN}

\section{A. Rancangan Penelitian}

Penelitian ini menggunakan pendekatan kuantitatif, menurut Sugiyono (2014: 13) penelitian kuantitatif adalah: Metode penelitian yang berdasarkan pada filsafat positivisme, digunakan untuk meneliti pada populasi atau sampel tertentu, pengumpulan data menggunakan instrumen penelitian, analisis data bersifat kuantitatif/statistik, dengan tujuan untuk menguji hipotesis yang telah ditetapkan.

Dengan kata lain, pendekatan kuantitatif dilakukan dengan cara pencatatan dan penganalisaan data hasil penelitian dengan menggunakan perhitungan statistik untuk mengukur variabel-variabel yang ada dalam penelitian (variabel $\mathrm{X}$ dan variabel $\mathrm{Y}$ ) dan mengetahui hubungan antar variabel tersebut.

Adapun metode yang digunakan dalam penelitian ini adalah metode deskriptif yang berarti menggambarkan suatu peristiwa atau masalah yang terjadi pada masa sekarang atau yang sedang berlangsung. Seperti yang 
dikemukakan Nasution (2009: 24), ciriciri dari metode deskriptif adalah:

a. Memusatkan diri pada pemecahanpemecahan masalah yang ada pada masa sekarang atau masalahmasalah yang aktual.

b. Data yang dikumpulkan mula-mula disusun, dijelaskan dan kemudian dianalisa, oleh karena itu metode ini sering disebut juga metode analisa.

Berdasarkan pendapat di atas, penelitian ini dimaksudkan untuk mendeskripsikan kondisi yang berkaitan dengan pengaruh kompetensi guru yang meliputi kompetensi pedagogik, kompetensi kepribadian, kompetensi sosial dan kompetensi profesional terhadap hasil belajar siswa dan mengukur sejauh mana hubungan antar variabel-variabel tersebut.

Sebagai tahap awal penelitian, penulis melakukan kunjungan ke SMA PGRI 109 Kota Tangerang pada tanggal 1 April 2017 untuk mengetahui lokasi dan mendapatkan informasi mengenai guru mata pelajaran IPS kelas XI. Kunjungan berikutnya merupakan observasi awal yaitu bertemu dengan guru mata pelajaran IPS kelas XI dan membicarakan mengenai rencana kegiatan penelitian beserta data yang dibutuhkan. Pada kesempatan tersebut penulis berkoordinasi dengan guru mata pelajaran IPS untuk jadwal penyebaran angket.

Pada tanggal 15 April 2017 penulis melakukan penyebaran angket tahap pertama terhadap sampel kelas XI MIA1 dan IIS-2. Penyebaran angket tahap kedua dilaksanakan tanggal 21 April 2017 terhadap sampel kelas XI MIA-2 dan IIS-1. Selama kegiatan tersebut penulis melakukan pengamatan terhadap kondisi kelas dan berkomunikasi dengan para siswa untuk mengetahui gambaran kegiatan belajar mata pelajaran IPS di kelas masingmasing.

Dalam rangka mendukung hasil pengisian angket siswa, penulis juga melakukan wawancara tertutup terhadap guru mata pelajaran IPS kelas XI yang dilaksanakan pada tanggal 20 Juli 2017.

\section{B. Populasi dan Sampel}

1. Populasi

Berdasarkan pendapat Arikunto (2010: 173) "populasi adalah keseluruhan objek penelitian". Sesuai dengan topik penelitian, maka yang menjadi populasi dalam penelitian ini 
adalah siswa kelas XI SMA PGRI 109 Kota Tangerang yang terdiri dari empat kelas, yaitu MIA-1, MIA-2, IIS-1 dan IIS-2. Jumlah kesuluruhan populasi adalah 137 siswa.

\section{Sampel}

Sesuai pendapat Sugiyono (2011: 86), "Makin besar jumlah sampel yang mendekati populasi, maka peluang kesalahan generalisasi semakin kecil dan sebaliknya makin kecil jumlah sampel menjauhi populasi, maka makin besar kesalahan generalisasi”. Pengambilan sampel dalam penelitian ini menggunakan teknik proportional simple random sampling, yaitu memberikan kesempatan yang sama bagi setiap unsur (anggota) populasi untuk ditetapkan sebagai sampel (Sugiyono, 2011: 63).

Untuk memenuhi syarat kerepresentatifan, penentuan jumlah sampel dihitung dengan menggunakan rumus Issac and Michael (Sugiyono, 2011: 126

Tabel Populasi Siswa Kelas XI SMA PGRI \begin{tabular}{|c|c|}
\hline \multicolumn{1}{|c|}{109 Kota Tangerang } \\
\hline Kelas & $\begin{array}{c}\text { Jumlah } \\
\text { Siswa }\end{array}$ \\
\hline XI MIA-1 & 34 siswa \\
\hline XI MIA-2 & 33 siswa \\
\hline XI IIS-1 & 35 siswa \\
\hline XI IIS-2 & 35 siswa \\
\hline Total & $\mathbf{1 3 7}$ siswa \\
\hline
\end{tabular} sumber: Data Siswa SMA PGRI

\section{Kota Tangerang}

Berdasarkan rumus Issac and Michael di atas, maka perhitungan jumlah sampel siswa kelas XI SMA PGRI 109 Kota Tangerang sebagai berikut:

$$
3,841 \times 137 \times 0,5 \times 0,5
$$

$$
\mathrm{s}=\frac{}{0,05^{2} \times(137-1)+3,841 \times 0,5}
$$$$
\text { x } 0.5
$$

$$
131,55
$$

$$
\begin{aligned}
& \mathrm{s}=\frac{}{0,0025 \times 136+3,841 \times 0,25} \\
& \mathrm{~s}=\frac{131,55}{0,0025 \times 136+0,96025} \\
& \mathrm{~s}=\frac{131,55}{\mathrm{~N}=} \\
& \mathrm{s}=\frac{131,55}{\mathrm{~s}=} \\
& \quad 101,30025
\end{aligned}
$$


Sampel per Kelas Siswa Kelas XI SMA PGRI 109 Kota Tangerang

\begin{tabular}{|c|c|c|c|c|}
\hline No & Kelas & Perhitungan & Hasil & $\begin{array}{c}\text { Jumlah } \\
\text { Sampel }\end{array}$ \\
\hline 1 & $\begin{array}{c}\text { XI } \\
\text { MIA-1 }\end{array}$ & $\begin{array}{c}34 / 137 \mathrm{x} \\
101\end{array}$ & 25,07 & $\begin{array}{c}25 \\
\text { siswa }\end{array}$ \\
\hline 2 & $\begin{array}{c}\text { XI } \\
\text { MIA-2 }\end{array}$ & $\begin{array}{c}33 / 137 \mathrm{x} \\
101\end{array}$ & 24,33 & $\begin{array}{c}24 \\
\text { siswa }\end{array}$ \\
\hline 3 & $\begin{array}{c}\text { XI } \\
\text { IIS-1 }\end{array}$ & $\begin{array}{c}35 / 137 \mathrm{x} \\
101\end{array}$ & 25,80 & $\begin{array}{c}26 \\
\text { siswa }\end{array}$ \\
\hline 4 & $\begin{array}{c}\text { XI } \\
\text { IIS-2 }\end{array}$ & $\begin{array}{c}35 / 137 \mathrm{x} \\
101\end{array}$ & 25,80 & $\begin{array}{c}26 \\
\text { siswa }\end{array}$ \\
\hline \multicolumn{3}{|c|}{ Total } & $\begin{array}{c}\mathbf{1 0 1} \\
\text { siswa }\end{array}$ \\
\hline
\end{tabular}

sumber: Diolah Oleh Penulis (2017)

Dengan demikian dari jumlah populasi siswa kelas XI sebanyak 137 orang, jumlah sampel yang akan digunakan adalah 101 orang siswa. Dari tiap-tiap kelas akan diambil 24-25 orang siswa sebagai data sampel seperti tampak pada tabel 3.3 di atas.

\section{Teknik Pengumpulan Data}

Teknik pengumpuan data yang digunakan dalam penelitian ini antara lain:

\section{Angket}

Dilakukan dengan cara memberikan beberapa pertanyaan atau pernyataan untuk di jawab oleh responden sebagai sampel penelitian (Sugiyono, 2011: 119). Angket yang digunakan adalah jenis angket tertutup dengan pilihan jawaban yang telah disediakan. Yang dijadikan sebagai responden atau sampel dalam penelitian ini adalah siswa kelas XI MIA-1, XI MIA-2, XI IIS-1 dan XI IIS-2 SMA PGRI 109 Kota Tangerang.

\section{Wawancara}

Untuk mengetahui hal-hal yang lebih mendalam, pengumpulan data juga dilakukan melalui wawancara. Dalam hal ini penulis menggunakan pedoman wawancara terstruktur, yaitu pedoman wawancara yang disusun secara terperinci sehingga menyerupai check-list. Wawancara dilakukan dengan guru mata pelajaran Ekonomi, serta untuk mengetahui faktor pendukung dan penghambat hasil belajar Ekonomi.

\section{Dokumentasi}

Yaitu mencari data berupa catatan peristiwa yang sudah berlalu (Sugiyono, 2013: 240). Catatan ini dapat berupa buku, transkip, notulen rapat, agenda, dan lain sebagainya. Dalam penelitian ini, penulis menggunakan data nilai mata pelajaran Ekonomi semester ganjil tahun 2016/2017 untuk mendapatkan gambaran tentang hasil belajar peserta didik. 


\section{Observasi}

Observasi dilakukan melalui pengamatan langsung ke lokasi penelitian yang berada di SMA PGRI 109 Kota Tangerang untuk memperoleh data tentang kondisi atau deskripsi lokasi penelitian

\section{Instrumen Penelitian}

Instrumen

penelitian berdasarkan pendapat Sugiyono (2011: 137) adalah "suatu alat yang digunakan untuk mengukur fenomena alam maupun sosial yang diamati”. Instrumen yang digunakan dalam penelitian ini berupa angket tertutup yang berisi 37 pertanyaan terkait kompetensi guru mata pelajaran Ekonomi, baik secara pedagogis, kepribadian, sosial maupun profesional dan hasil belajar siswa.

\section{E. Pembahasan}

Merujuk pada hasil analisis data dan kajian teori terkait pembahasan hasil penelitian, maka diperoleh gambaran dan kesimpulan atas pengarauh kompetensi guru terhadap hasil belajar.

1. Kompetensi Guru Mata Pelajaran Ekonomi Siswa Kelas XI SMA PGRI 109 Kota Tangerang

Berdasarkan hasil jawaban responden melalui angket atas pertanyaan terkait kompetensi guru menunjukan bahwa mayoritas responden memberikan penilaian yang baik terhadap kompetensi guru mata pelajaran Ekonomi. 92\% atau 93 dari 101 responden memberikan penilaian "baik" terkait tingkat kompetensi guru mata pelajaran ekonomi. Sedangkan sisanya, $8 \%$ responden atau 8 siswa menilai "cukup".

Kompetensi guru dalam penelitian ini mencakup kompetensi pedagogis, sosial, kepribadian dan profesional sebagai suatu kesatuan yang tidak dapat dipisahkan sebagai kompetensi yang harus dimiliki oleh seorang guru sesuai dengan yang diamanatkan dalam Undang-Undang No. 14 tahun 2005 tentang Guru dan Dosen.

2. Hasil Belajar Mata Pelajaran Ekonomi Siswa Kelas XI SMA PGRI 109 Kota Tangerang

Menurut Paul A. Samuelson dalam Sukwiaty, dkk. (2009: 120) mata pelajaran ekonomi adalah materi pembelajaran yang mempelajari tentang perilaku orang dan masyarakat dalam memilih cara menggunakan sumber daya yang langka dan memiliki beberapa alternatif penggunaan, dalam rangka memproduksi berbagai 
komoditas,

untuk kemudian menyalurkannya, baik saat ini maupun di masa depan kepada berbagai individu dan kelompok yang ada dalam suatu masyarakat. Sehingga mata pelajaran ekonomi merupakan salah satu mata pelajaran penting yang sebaiknya dipahami oleh setiap siswa.

Melalui hasil angket, diperoleh jawaban bahwa mayoritas yaitu 76 dari 101 responden atau sebesar 75\% memperoleh hasil belajar yang "baik", $12 \%$ responden atau 12 siswa mencapai hasil belajar yang "sangat baik" dan sisanya $13 \%$ responden atau 13 siswa memiliki hasil belajar yang "cukup". Dengan demikian dapat ditarik kesimpulan bahwa hasil belajar mata pelajaran ekonomi pada siswa kelas XI di SMA PGRI 109 berada pada tingkat yang baik. Data yang diperoleh melalui hasil angket ini juga didukung oleh data hasil test siswa.

3. Pengaruh Kompetensi Guru Terhadap Hasil Belajar Mata Pelajaran Ekonomi Siswa Kelas XI SMA PGRI 109 Kota Tangerang

Berdasarkan hasil analisa data yang diperoleh melalui angket yang dibagikan secara langsung kepada 101 siswa kelas XI di SMA PGRI 109 Kota
Tangerang, diperoleh hasil sebagai berikut:

a. Uji prasyarat analinis terhadap instrumen dalam penelitian ini menunjukan hasil yang valid dan reliabel.

1) Nilai Corrected Item - Total atau $\mathrm{r}_{\text {hitung }}$ dari tiap indikator kompetensi guru, yaitu kompetensi pedagogis, kompetensi sosial, kompetensi kepribadian dan kompetensi profesional memiliki nilai lebih besar dari $r_{\text {tabel }}(0,196)$. Dengan demikian maka dapat dikatakan bahwa hasil uji validitas terhadap seluruh indikator variabel independen menujukan hasil yang valid. Instrumen yang valid artinya menunjukan bahwa instrument tersebut dapat digunakan untuk mengukur apa yang seharusnya diukur (Sugiyono, 2015: 173).

2) Uji reliabilitas menunjukan tingkat reliabilitas yang sangat tinggi dengan nilai Cronbach's Alpha sebesar 0,877. Menurut Ghozali (2016: 47) sebuah angket dikatakan reliabel apabila responden memberikan jawaban yang konsisten atas setiap pernyataan. 
b. Dari hasil uji asumsi klasik yang mencakup uji normalitas dan heteroskedastisitas, diperoleh kesimpulan bahwa data yang digunakan dalam penelitian ini memiliki distribusi normal dan terbebas dari masalah heteroskedastisitas.

c. Pengujian atas hipotesis menunjukan terdapat pengaruh kompetensi guru terhadap hasil belajar mata pelajaran Ekonomi siswa kelas XI SMA PGRI 109 Kota Tangerang.

1) Nilai konstanta $(\alpha)$ yang ditunjukan oleh hasil analisis regresi linear sederhana sebesar 18,430 . Nilai ini memiliki arti bahwa apabila kompetensi guru diasumsikan nol atau tidak ada, maka nilai konsisten hasil belajar adalah sebesar 18,430.

2) Angka koefisien regresi variabel kompetensi guru pada hasil analisis regresi linear sederhana adalah 0,186, artinya apabila variabel lainnya tetap dan kompetensi guru mengalami kenaikan 1 satuan, maka hasil belajar akan mengalami peningkatan sebesar 0,186 .

3) Berdasarkan hasil analisa data yang diperoleh melalui perhitungan statistik koefisien determinasi, diperoleh nilai $\mathrm{R}_{\text {square }}$ sebesar 0,181 . Angka ini menjelaskan bahwa kompetensi guru memiliki pengaruh sebesar $18,1 \%$ terhadap hasil belajar, sedangkan sisanya $81,9 \%$ dipengaruhi oleh faktorfaktor lain di luar penelitian ini.

4) Apabila $t_{\text {hitung }}<t_{\text {tabel, maka }} H_{o}$ diterima dan $\mathrm{H}_{\mathrm{a}}$ ditolak. Sebaliknya, apabila $t_{\text {hitung }}>t_{\text {tabel }}$, maka $\mathrm{H}_{\mathrm{o}}$ ditolak dan $\mathrm{H}_{\mathrm{a}}$ diterima. Berdasarkan hasil uji statistik $\mathrm{t}$ diperoleh nilai $t_{\text {hitung }}$ sebesar 5,109. Adapun nilai $t_{\text {tabel }}$ untuk jumlah responden 101 dengan $\mathrm{dk}=\mathrm{n}-\mathrm{k}-1$ dan $\alpha=0,05$ adalah 1,664. Dengan demikian $t_{\text {hitung }} 5,109>\mathrm{t}_{\text {tabel }} 1,664$, nilai ini menunjukan bahwa terdapat pengaruh kompetensi guru terhadap hasil belajar mata pelajaran ekonomi siswa kelas XI SMA PGRI 109 Kota Tangerang.

\section{Kesimpulan}

Berdasarkan masalah penelitian yang telah dirumuskan dan hasil penelitian yang telah dilakukan, penulis mengambil kesimpulan sebagai berikut:

1. Kompetensi guru mata pelajaran Ekonomi kelas XI di SMA 109 
Kota Tangerang berdasarkan hasil angket menunjukan tingkat yang baik. Hampir seluruh responden sebanyak 93 siswa atau 92\% memberikan penilaian "baik" atas kompetensi guru mata pelajaran ekonomi, dan sisanya 8 siswa atau 8\% menilai "cukup".

2. Hasil belajar siswa kelas XI pada mata pelajaran Ekonomi di SMA 109 Kota Tangerang dapat disimpulkan baik. Hal ini bisa dilihat dari jawaban responden melalui angket yang diberikan kepada 101 siswa kelas XI. Mayoritas responden yaitu $75 \%$ memiliki hasil belajar yang "baik", $12 \%$ responden mencapai hasil belajar yang "sangat baik" dan sisanya $13 \%$ responden memiliki hasil belajar yang "cukup".

3. Berdasarkan hasil analisa regresi linear sederhana, koefisien regresi menunjukkan angka positif sebesar 0,816 sehingga dapat ditarik kesimpulan bahwa terdapat pengaruh positif kompetensi guru terhadap hasil belajar mata pelajaran Ekonomi siswa kelas XI SMA PGRI 109 Kota Tangerang. Hal ini berarti semakin tinggi kompetensi yang dimiliki oleh seorang guru maka semakin tinggi hasil belajar yang diperoleh oleh siswa, begitu pula sebaliknya. Dengan demikian, kompetensi guru sangat diperlukan dalam proses pembelajaran demi meningkatkan hasil belajar siswa. Melalui perhitungan nilai $\mathrm{R}_{\text {square }}$, kompetensi guru pada SMA PGRI 109 Kota Tangerang memiliki pengaruh sebesar $18,1 \%$ terhadap hasil belajar siswa, sedangkan sisanya $81,9 \%$ dipengaruhi oleh faktor-faktor lain di luar penelitian ini.

\section{DAFTAR RUJUKAN}

A.M., Sardiman. 2007. Interaksi dan Motivasi Belajar Mengajar. Jakarta: PT. Raja Grafindo Persada

Andriawati, Eka. 2013. Pengaruh Kompetensi Pedagogik Guru Terhadap Hasil Belajar Siswa Pada Mata Pelajaran Ekonomi di SMA. Jurnal Pendidikan dan Pembelajaran. Vol 2, No. 10, http://jurnal.untan.ac.id/index.p hp/ jpdpb/article/view/3729. Diakses 7 Pebruari 2016

Arikunto, Suharsimi. 2013. Dasardasar Evaluasi Pendidikan. Jakarta: Bumi Aksara 
Arikunto, Suharsimi. 2010. Prosedur penelitian : Suatu Pendekatan Praktik. Jakarta: Rineka Cipta

Asep Jihad \& Abdul Haris. 2008. Evaluasi Pembelajaran. Yogyakarta: Multi Pressindo

Asmani, Jamal Ma'mur. 2009. 7 Kompetensi

Menyenangkan Guru Profesional. Yogyakarta: Power Books (IHDINA)

Azzahra, Aroma Fatimah. 2015. Pengaruh Kompetensi Guru Terhadap Hasil Belajar Siswa Pada Mata Pelajaran Ilmu Pengetahuan Sosial di SMP Plus Al-Kaustar Blingbing Malang. Skripsi tidak diterbitkan. Malang: Program Sarjana Pendidikan Universitas Islam Negeri Malang.

Bloom, Benjamin S.1970.Taxonomy of Education Objectives the Clasification, dalam Agus Suprijuno 2010 - Teori dan aplikasi Paikem. Yogyakarta : Pustaka Belajar

Bloom (dalam Sudjana). 2010. Penilaian Hasil Proses Belajar Mengajar. Bandung: Remaja Rosdakarya

Chotimah, Husnul. 2008. Menelusuri Kriteria Guru Ideal Abad 21. Malang: Koran Pendidikan Online. Senin, 19 Mei, http://www.koranpendidikan. com/artikel/805/menelusurikriteria-guru-ideal-abad- 21.html. Diakses 14 Pebruari 2016

Dave, RH. 1967. Lifelong Education and School Curriculum. UNESCO Institute Monographs, Whole No. 1

Depdikbud. 1991. Kamus Besar Bahasa Indonesia. Jakarta: Balai Pustaka

Elfachmi, Amin Kuneifi. 2016. Pengantar Pendidikan. Jakarta: Penerbit Erlangga.

Fananie, Zainuddin. 2010. Pedoman Pendidikan Modern. Jakarta: Fananie Center

Gagne (dalam Suprijono). 2010. Cooperative Learning. Yoyakarta: Pustaka Belajar

Ghozali, Imam. 2011. Aplikasi Analisi Multivariat dengan Program SPSS. Semarang: Badan Penerbit Universitas Diponegoro

Ghozali, Imam. 2016. Aplikasi Analisi Multivariat dengan Program SPSS. Semarang: Badan Penerbit Universitas Diponegoro

Hamalik, Oemar. 2008. Kurikulum dan Pembelajaran. Jakarta: Bumi Aksara

Nurmayanti, Irma. 2013. Pengaruh Kompetensi Guru Terhadap Prestasi Belajar Siswa Studi: Pada Mata Pelajaran Akuntansi Kelas XI IPS Di SMA Pasundan Se-Kota Bandung. Tesis tidak diterbitkan. Bandung: Program 
Sarjana Pendidikan Universitas Pendidikan Indonesia.

Nasution. 2009. Metode Research. Jakarta : PT. Bumi Aksara

Paul A. Samuelson (dalam Sukwiaty dkk.). 2009. Pengertian Ilmu Ekonomi. Jakarta: Rineka Cipta

Peraturan Pemerintah No. 19 tahun 2005 tentang Standar Pendidikan Nasional

Purwanto. 2014. Evaluasi Hasil Belajar. Yogyakarta: Pustaka Pelajar

Rusman, 2011. Model-Model Pembelajaran Mengembangkan Profesionalisme Guru. Jakarta: PT. Raja Grafindo

Slameto. 2010. Belajar dan FaktorFaktor yang Mempengaruhinya. Jakarta: Rineka Cipta

Soeratman, Ki. 1987. Pokok Pokok Ketamansiswaan. Yogyakarta: Majelis Luhur Persatuan Tamansiswa

Statistika Terapan. 2009. Mengapa Koefisien Determinasi Bisa Kecil. www.statistikaterapan.wordpres s.com/2009/01/22/mengapakoefisien-determinasi-bisakecil/. Diakses 1 Agustus 2017

Sudjana. 2009. Penilaian Hasil Proses Belajar Mengajar. Jakarta: Rineka Cipta

Sudjana, Nana. 2008. Penilaian Hasil Proses Belajar Mengajar.
Bandung: PT. Remaja

Sugiyono. 2009. Metode Penelitian Kuantitatif dan Kualitatif. Bandung: CV. Alfabeta

Sugiyono. 2011. Metode Penelitian Kuantitatif, kualitatif dan $R$ \& $D$. Bandung: CV. Alfabeta

Sugiyono. 2012. Memahami Penelitian Kualitatif. Bandung: CV. Alfabeta

Sugiyono. 2013. Metode Penelitian Pendidikan (Pendekatan Kuantitatif, Kualitatif dan $R \& D)$. Bandung: CV. Alfabeta

Sugiyono. 2013. Statistika Untuk Penelitian. Bandung: CV. Alfabeta

Sugiyono. 2014. Metode Penelitian Kuantitatif, kualitatif dan $R$ \& $D$. Bandung: CV. Alfabeta

Sukmadinata, Nana S. 2007. Landasan Psikologi Proses Pendidikan. Bandung: Remaja Rosdakarya

Suparlan. 2008. Menjadi Guru Efektif. Jakarta: Hikayat Publishing

Suprihatiningrum, Jamil, 2013. Guru Profesional. Yogyakarta: ArRuzz Media.

Undang-Undang Republik Indonesia No. 20 tahun 2003 tentang Sistem Pendidikan Nasional

Undang-Undang Republik Indonesia No. 14 tahun 2005 tentang Guru dan Dosen 
